\title{
An Evaluation of 'Get Smart' English Language Textbook from the Perspectives of English Teachers
}

\author{
Ghazi Mohammad Takal ${ }^{1 *}$ Department of English, Faculty of Languages and Literature, \\ Ghazni University, Ghazni, Afghanistan \\ Thilashiny Planisamay ${ }^{2}$, Nur Anisa Binti Ibrahim Gani ${ }^{2}$, Clara Vellangani Peter ${ }^{2}$, \\ Manmit Kaur A/P Paranjit Singh ${ }^{2}$,School of Education, Faculty of Social Sciences and \\ Humanities, Universiti Teknologi Malaysia, 81310 UTM Johor Bahru, Johor, Malaysia \\ Abdul Rahmat ${ }^{3}$ Department of Nonformal Education Universitas Negeri Gorontalo, \\ Indonesia, abdulrahmat@ung.ac.id
}

Corresponding Author: ghazitakal@gmail.com

Received: 04 March 2021; Revised: 26 April 2021; Accepted: 28 April 2021

DOI: http://dx.doi.org/10.37905/aksara.7.2.727-746.2021

\begin{abstract}
This study aimed to evaluate Get Smart year three ELT textbook. A mixed method design of quantitative questionnaires and qualitative interviews was used. Thirtyeight ESL lecturers from primary schools in Malaysia have been studied for their perspectives on Get Smart textbook. The quantitative questionnaires were analyzed for descriptive statistics and interviews were analyzed thematically. The findings from both questionnaire and interviews showed that Get Smart is one of the most useful books for ELT in primary schools in Malaysia. However, there were some parts which need to be improved such as the lack of creativity in illustrations, challenging vocabulary, the social and cultural mismatch, use of difficult words in grammar explanations, lack of sentence and paragraph structures in the writing part. These findings show that Get Smart textbook is suitable but still there are some parts that need improvement.
\end{abstract}

Keywords: Evaluation, English Language Textbook, Teachers

\section{INTRODUCTION}

While realizing on the vitality of being on par with other globalized and developed nations, it is always the Ministry of Education's concern on improving the education system specifically the English language. This further explains the reasons beyond the educational reforms seen nowadays. Despite the intelligent move towards meeting the global standards through the implementation of Common European Framework of Reference for Languages by means of Malaysian Education Blueprint 2013-2015 and Roadmap for English Language Education 2015-2025, there is a list of issues to be dealt with to fulfil the aspiration. CEFR marks a crucial reform within the ELT sphere specifically in terms of curriculum and methodology with the rise in concerns among the stakeholders on the quality and suitability of the teaching materials used specifically the textbook. Therefore, there is a need to carefully evaluate the quality and suitability of the textbook used. 
This study aims to explore the strengths and weaknesses of the Get Smart textbook used for year 3 in Malaysian primary schools as well as to certify it with respect to the characteristics of a good ELT textbook.

\section{Literature Review}

\section{The Roles of Textbook in ELT Classroom}

Indeed, while discussing thoroughly on the importance of textbooks in ELT classroom, we arrive at the conclusion that textbook plays crucial roles in ELT classroom with respect to pedagogical reasons and learners' needs. First and foremost, Richards Jack and Rodgers (2001) suggest that textbook provides structure and syllabus which determine the impact of a particular learning programme. This structure carves the way forward towards achieving the goal of language learning for both teachers and learners.

In addition, as proposed by Demir and Ertas (2014) textbooks are perceived as the unique contributors to content learning which marks on their roles of providing input for the learners. Using textbook in an ELT classroom provides the learners with similar content. eventually putting it easier for a standardized assessment as clarified by AbdelWahab (2013) that it can actually "guarantee that students in different classes will receive a similar content and therefore, can be evaluated in the same way". Alternatively stated, the use of textbook can ensure uniformity and standard-setting in different instructional environment.

\section{The Characteristics of a Good Textbook}

Textbook selection is pertinent to ensure successful language learning and acquisition as textbook serves as the main reference for educators and learners which is referred continuously throughout the teaching and learning processes (McGrath, 2002).

\section{The Vitality of Textbook Evaluation}

Textbook when viewed as a central element in an ELT classroom proposed a dire need towards an evaluation with respect to the characteristics of a good textbook. This evaluation process provides an accurate and deep understanding on the textbook as a whole for those relevant stakeholders. Firstly as suggested by Sheldon (1988) a textbook evaluation is absolutely paramount for teachers or program developer; further assisting the decision-making and materials' selection process. In essence, the strengths and weaknesses highlighted in the findings of an evaluation bring forth insights into the quality, effectiveness and suitability of the textbook with respect to the learners' needs as well as the programme's objectives. This theoretical understanding bring forward a practical view which aids the programme developers and teachers as cited by Nimehchisalem and Mukundan (2015) to make decisions in selecting an ideal book for a particular language course

Secondly, an evaluation of textbook is significant for teachers' professional development as it is a process of critically examining and exploring the potential of 
a material and as stated by Demir and Ertas (2014) "enabling them to scrutinize the course material with an academic perspective". Besides, as pointed by Tomlison (2001) that course materials specifically textbook evaluation is also regarded as an action research which contributes towards an understanding of the ways in which the material works. Thus, through this action research, a reflective teacher can adapt and adopt the content of the textbook (Nimehchisalem \& Mukundan, 2015) by taking into account its' merits and demerits to meet the contextual needs of the learners. Putting it differently, textbooks evaluation is undeniably crucial and is strongly recommended by several theorists to meet the contextual needs of the students

Textbook evaluation is basically a straightforward, analytical 'matching process: matching needs to available solutions' (Hutchinson \& Waters, 1987, p. 97, cited in Sheldon, 1988). However, Sheldon (1988, p. 237) explains that course books, whether we like it or not, representing for both students and teachers the visible heart of any ELT program. There are situations which necessitate evaluating language learning materials. ELT materials evaluation in general addresses the systematic assessment of the value of materials in relation to their objectives and objectives of learners using them ((Soleimani \& Dabbaghi, 2012).

Many teachers have had the responsibility of evaluating textbooks. Often, teachers have not been confident about what to base their judgments on, how to qualify their decisions, and how to report the results of their assessment. Teachers, students, and administers are all consumers of textbooks. Every single one of them may have conflicting views about what a good/standard textbook is (Ansary \& Babaii, 2002). In a situation where there is considerable professional, financial and even political investment, the selection of a particular core volume signals an executive educational decision. The definition and application of systematic criteria for assessing course books are vital, as shown by this high profile (Sheldon, 1988).

\section{RESEARCH METHODOLOGY}

The current study was conducted through a mixed method design. There was a quantitative questionnaire made from checklist and qualitative interviews. Mixed method design, as Creswell and Clark believe can provide best understanding regarding the problem being studied compared to a single-method design. Miles, Huberman, Huberman, and Huberman (1994) also believe that the combination of qualitative and quantitative data make a powerful mix. The participants for the study were 38 ESL (English as a Second Language) teachers from SK/SJKT/SJKC primary schools, in Johor Bahru, Malaysia. Their age ranged from 28 to 45 . Majority of them had a minimum of 1-5 years of teaching experience. Two instruments were used in the study which consisted of quantitative questionnaire and qualitative interviews. The quantitative questionnaire was the adopted version of textbook evaluation checklists from four sources (Tomlison, et al,2001 ; Ereksoussy (1993); Thein (2006) and Al-Hajailan (2003) by Alamri's (2008) but the modified version of (Akef \& Moosavi, 2014) was used to suit the current study. It is based on a Likert Scale of 1-4 where 1 stands for strongly 
disagree and 4 shows strongly agree. The questionnaire has two sections which the first part is about demographics and the second part is the evaluation. The demographics had four parts which were gender, teaching experience, qualifications and evaluation experience. The second section had eight main themes each one with corresponding number of items. Items $(1,2,3)$ were for general appearance, items $(4,5,6,7,8,9,10,11)$ were for design and illustration, items $(12 \&$ 13) for accompanying materials, items $(14,15,16,17,18)$ for topic contents, items $(19,20,21,22,23,24)$ for language contents, items $(25,26,27)$ for social and cultural context, items $(28,29,30,31,32,33)$ for language skills, items $(34,35,36,37,38)$ for activities and exercises. Quantitative questionnaires, according to Cohen, Manion, Morrison, and Morrison (2007), can be used to gather data about specific events and to describe their nature and find the relationships between different events. As the questionnaire was adopted, the reliability has already been tested by previous researcher through internal consistency method. It was found that the overall reliability of eight items in the questionnaire was 0.75 Cronbach's Alpha. This was an acceptable reliability range as believed by Radhakrishna (2007) that reliability coefficient of 0.70 is an acceptable degree. The second instrument used in the current study was semi-structured interviews with 3 informants who already responded the quantitative questionnaire. According to Cohen et al. (2007),interviews can enable humans to talk about their meaning of the world they live in and their interpretation of the events. Bryman, Becker, and Sempik (2008) also believe that semi-structured interviews enable the respondents to remain open. The questions for interview were established based on the preliminary findings to find an in-depth understanding regarding the teachers' perspectives about Get Smart year three textbook. The materials used in the current study was Get Smart Year 3 Textbook which is taught in year three in primary schools in Malaysia. The book is written by H. Q. Mitchell and Marileni Malcogianni. The overall length of the books is 133 pages which consists of 10 modules. Each module of the book contains separate sections for vocabulary and structures.

First of all, the quantitative questionnaires were sent online to the teachers who teach in primary school. Online data collection is very popular these days. According to Skarupova and Blinka (2013), online data collection is commonly used in research since systematic data can be collected through online questionnaires. In addition, it is economical (Dörnyei \& Taguchi, 2009). After the quantitative data were gathered, they were analyzed for preliminary findings in order to derive the interview questions. Three of the respondents were interviewed for gaining more information about their perspective of Get Smart year three textbook. After that, data were analyzed for findings. Data analysis is one of the important stages of a study as believed by (Malterud (2001) and Sandelowski (1995) that systematically analyzed data can be communicated transparently to the readers. The quantitative questionnaire used in the current study was analyzed through SPSS IBM Version 25 for descriptive statistics of central tendency (mean, standard deviation and frequency). Descriptive statistics is used for parametric data to find how they are spread and where the centre is. The interviews were analyzed 
through thematic network analysis. According to King, Cassell, and Symon (2004), thematic analysis is a very flexible method and can be modified for different studies. This method of analysis can bring very rich data.

\section{FINDINGS AND DISCUSSIONS}

Data were analyzed through SPSS IBM Version (25) for descriptive statistics (mean, standard deviation, frequency ). Both the results of questionnaire and interviews are discussed below to answer the research questions of the study. The overall results from the questionnaire show that the average mean for all categories included in the questionnaire is 3.18. This reveals that generally, the respondents agree to all items of questionnaire and there is no any negative views regarding the Get Smart textbook. The highest mean (3.44) is coming from category A (General Appearance) in the questionnaire which implies that the appearance of the book is suitable and teachers are satisfied with it. Nonetheless, the lowest mean (2.73) is pertinent to category F ( Social and Cultural Contexts) implying that the respondents do not agree with the Get Smart textbook in terms of meeting the social and cultural contexts. In the following sections, the findings are presented and discussed based on the data gathered from the questionnaire.

\section{General Appearance}

Table 1 below indicates the descriptive statistics for the results from category A (General Appearance). It is noted that the mean obtained for this particular category is 3.44 i.e. emphasising on the agreement among most of the participants on the appropriateness of cover, font type and size as well as the title for each lesson. Specifically, all the respondents $(100 \%)$ agree that there is a suitable title for every lesson in Get Smart textbook while $97.4 \%$ agree with the suitability of the font size and type for the learners. These findings are also consistent with the findings of Akef and Moosavi (2014) and Momand et.al (2019) where they used the same questionnaire used in the current study. Akef and Moosavi (2014) found that the majority of the Iranian participants agreed or strongly agreed with the general appearance of the EFL textbook (Passages, Second Edition). In addition, Alamri (2008), who evaluated the ELT textbook in Saudi Arabia through using the same checklist but without adaptation found that the teachers agreed with the general appearances of the book, however, there were some points to be improved in terms of glossary of the book. General appearance of a textbook is perceived as one of the important criteria of a good textbook as it is where the learner's first impression lies on (Sarem, Hamidi, \& Mahmoudie, 2013). Furthermore, as pointed out by Chegeni, Kamali, Noroozi, and Chegeni (2016) and Sarem et al. (2013), it is of paramount importance to consider the size and format of print in a textbook which reflects on the strengths of Get Smart textbook as most of the participants agreed on the suitability of the font type and size in Get Smart textbook. These findings suggest that Get Smart textbook is effective in terms of its general appearance as general 
appearance (layout) plays a significant role in a textbook effectiveness (Mukundan \& Kalajahi, 2013).

Table 1: Teachers' perception on the general appearance of Get Smart

\begin{tabular}{|l|l|l|l|l|l|l|}
\hline Statement & SA & A & D & SD & Mean & STD \\
\hline 1.The cover is informative and attractive. & $50 \%$ & $\begin{array}{l}42.1 \\
\%\end{array}$ & $\begin{array}{l}7.9 \\
\%\end{array}$ & $\begin{array}{l}0 \\
\%\end{array}$ & 3.42 & 0.64 \\
\hline $\begin{array}{l}\text { 2.The font type and size used in the series } \\
\text { are appropriate for the learners. }\end{array}$ & $\begin{array}{l}55.3 \\
\%\end{array}$ & $\begin{array}{l}42.1 \\
\%\end{array}$ & $\begin{array}{l}2.6 \\
\%\end{array}$ & $\begin{array}{l}0 \\
\%\end{array}$ & 3.52 & 0.55 \\
\hline Statement & SA & A & D & SD & Mean & STD \\
\hline 3.Every lesson is given an appropriate title. & $\begin{array}{l}39.5 \\
\%\end{array}$ & $\begin{array}{l}60.5 \\
\%\end{array}$ & $0 \%$ & $\begin{array}{l}0 \\
\%\end{array}$ & 3.39 & 0.49 \\
\hline Overall Mean & \multicolumn{7}{|l|}{3.44} & \\
\hline Overall Standard Deviation & \multicolumn{7}{|l|}{0.69} & \\
\hline
\end{tabular}

$\mathrm{SA}=$ Strongly Agree, $\mathrm{A}=$ Agree, $\mathrm{N}=$ Neutral, $\mathrm{D}=$ Disagree, $\mathrm{SD}=$ Strongly Disagree, $\mathrm{STD}=$ Standard Deviation

\section{Language Skills}

Table 2 below shows that the overall mean for this category is 3.26 being the second highest mean which suggests the agreement of teachers on the suitability of the language skills in Get Smart textbook .Majority of participants (92.4\%) agreed that the textbook has adequately covered all the four skills of the language. The table shows that majority of the participants (93.1\%) agreed that the listening skill is highly focused among other skills in terms of authenticity, background information, questions and its-related exercises. This is a promising point since the four skills of the language are the pinnacle of language which will eventually take learners to greater heights (Lorena, 2015). Lorena further states that, these four skills are separate and stands by their own, yet they are an inseparable bond which bounds together. According to Lorena (2015), listening and speaking are skills that are highly interrelated and simultaneously work in real life situations.

These two skills aim to foster effective oral communication. They will assure purposeful communication in real life situations. Thus, they are needed first as a kind of input before learners engage in reading and writing. Regarding reading and writing, Lorena (2015) believes that they form a strong relationship for achieving 
effective written communication. These findings are conflicting with the study of Alamri (200) and Momand et al., (2019). Alamri found that the grade 6 school ELT textbook had more focus on reading and writing which is considered a shortcoming. Alamri argued that students needed to grasp the language in terms of vocabulary, grammar and pronunciation before they engage in a conversation. In addition, Momand et al found in their study that the language skills in KSSR year 6 ELT textbook taught in primary school are inadequately covered. Fortunately, the teachers in this study believed that the book has given more weight to listening and this can be sensible since this book is designed for primary students and they need a lot of input before they produce any output. Listening is the essential skills of the language as argued by Elizabeth and Rao (2007) that listening comes first in language learning and when the child learns, the language he needs listening first. Also, Glanz (2004) believes that listening is the foundation of all other skills in language learning. This does not mean to neglect other skills of the language but listening should be given some more consideration. Thus, these findings imply that Get Smart is a suitable book for students in terms of taking into consideration the language skills.

Table 2: Teachers Perception on Language Skills in Get Smart

\begin{tabular}{|l|l|l|l|l|l|l|}
\hline \multicolumn{1}{|c|}{ Statement } & SA & A & D & SD & Mean & STD \\
\hline $\begin{array}{l}\text { 28.The four skills (listening, speaking, } \\
\text { reading, and writing) are adequately } \\
\text { covered. }\end{array}$ & $44.7 \%$ & $47.4 \%$ & $7.9 \%$ & $0 \%$ & 3.37 & 0.63 \\
\hline $\begin{array}{l}\text { 29.There is material for integrated skills } \\
\text { work. }\end{array}$ & $36.8 \%$ & $57.9 \%$ & $5.3 \%$ & $0 \%$ & 3.31 & 0.57 \\
\hline $\begin{array}{l}30 . \text { Listening material is well recorded, as } \\
\text { authentic as possible, and accompanied by } \\
\text { background information, questions, and } \\
\text { activities. }\end{array}$ & $39.5 \%$ & $52.6 \%$ & $7.95 \%$ & $0 \%$ & 3.31 & 0.612 \\
\hline $\begin{array}{l}31 . \text { There is sufficient reading material. } \\
\text { (There is a range of varied and interesting } \\
\text { reading text that can engage students } \\
\text { cognitively and effectively.) }\end{array}$ & $39.5 \%$ & $47.4 \%$ & $10.5 \%$ & $2.6 \%$ & 3.24 & 0.75 \\
\hline $\begin{array}{l}32 . \text { There is sufficient material for spoken } \\
\text { English (e.g. dialogues, role-plays, etc.) }\end{array}$ & $42.1 \%$ & $44.7 \%$ & $13.2 \%$ & $0 \%$ & 3.30 & 0.69 \\
\hline
\end{tabular}




\begin{tabular}{|c|c|c|c|c|c|c|}
$\begin{array}{l}\text { 33.Writing activities are suitable in terms of } \\
\text { length, degree of accuracy, and amount of } \\
\text { guidance. }\end{array}$ & $28.9 \%$ & $52.6 \%$ & $15.8 \%$ & $2.6 \%$ & 3.08 & 0.75 \\
\hline Overall Mean & \multicolumn{3}{|c|}{3.26} \\
\hline Overall Standard Deviation & \multicolumn{2}{|c|}{0.10} \\
\hline
\end{tabular}

\section{Topic Contents}

Table 3 below shows that the mean for the category of Topic Contents is 3.25 which suggests the agreement of most of the teachers on the suitability of the topic contents of the textbook. Three items $(14,16$ and 17) are recorded as having the highest mean (3.31). In essence, the majority (92.1\%) of the teachers agreed that the textbook consists of interesting, motivating and non-embarrassing topics which allow students to think critically with the exception of only $7.9 \%$ of them. These findings are consistent with that of Moosavi and Akef (2014) and Moman et al., (2019) who found through the same instruments that the ELT books were appropriate in terms of topic contents. This is in accordance with the notion of Alshehri (2012) on the significance of interesting and motivating topics to grab students' attention eventually enhancing learning. In other words, as mentioned by Cunningsworth (1995) the topics should be developed with close reference on the learners' needs as failure to do so might impede the overall learning process especially in terms of grabbing and sustaining the learners' attention. Above all, as stated by Johar \& Aziz (2019), the quality of contents contributes on learners' personal and intellectual development. Indeed, topic content is considered as one of the strengths of Get Smart textbook.

Table 3: Teachers' Perceptions on Topic Contents of Get Smart Textbook

\begin{tabular}{|l|l|l|l|l|l|l|}
\hline Statement & SA & A & D & SD & Mean & STD \\
\hline $\begin{array}{l}\text { 14.The topics of the series are interesting and } \\
\text { motivating to learners. }\end{array}$ & $39.5 \%$ & $52.6 \%$ & $7.9 \%$ & $0 \%$ & 3.31 & 0.61 \\
\hline $\begin{array}{l}\text { 15.The topics encourage students to express } \\
\text { their own views. }\end{array}$ & $31.6 \%$ & $52.6 \%$ & $15.18 \%$ & $0 \%$ & 3.15 & 0.67 \\
\hline $\begin{array}{l}\text { 16.The series avoids potentially embarrassing or } \\
\text { disturbing topics. }\end{array}$ & $39.5 \%$ & $52.6 \%$ & $7.9 \%$ & $0 \%$ & 3.31 & 0.61 \\
\hline
\end{tabular}




\begin{tabular}{|l|l|l|l|l|l|l|} 
17.The topics allow students to think critically. & $39.5 \%$ & $52.6 \%$ & $7.9 \%$ & $0 \%$ & 3.31 & 0.61 \\
\hline 18.The topics are generally realistic. & $36.8 \%$ & $47.4 \%$ & $13.2 \%$ & $\begin{array}{l}2.6 \\
\%\end{array}$ & 3.18 & 0.76 \\
\hline Overall Mean & \multicolumn{3}{|c|}{3.25} \\
\hline Overall Standard Deviation & \multicolumn{3}{|c|}{0.08} \\
\hline
\end{tabular}

\section{Design and Illustration}

Table 4 below indicates the descriptive statistics for Design and Illustration in the questionnaire. This category covers a wide array of elements ranging from illustrations, table of contents, glossary, availability of white space, layout and the overall design of the textbook, Based on the data, most participants agreed on the effectiveness of the design and illustration of Get Smart with the overall mean of 3.23. While carefully examining on each item, it can be seen that item no. 4 obtained the highest mean which is 3.52 which implies that almost all the participants $(97.4 \%)$ consider that the textbook design is appropriate and clear which correlates with one of the universal features for an effective textbook pointed out by Ansari and Babaii (2002) which is the design or physical make-up of a textbook. In addition, this could contribute to the facilitation of learning as well as believed by Chegeni et. al (2016) that the attractive illustrations of a textbook can facilitate learning.

However, the lowest mean in this category is for item number 9 which is 2.21 indicating that a total of $50 \%$ from the participants felt that the illustrations in the textbook do not stimulate the students to be creative. This might be due to the fact that the illustrations are quite unfamiliar with the learners' prior knowledge and daily lives. These findings are consistent with that of Alamri (2208) who found that teachers agreed with the design and illustration of the book while disagreeing with the idea that the illustrations could motivate students for creativity. These findings are different from the findings from Moosavi and Akef (2014) where they found that students and teachers disagreed with the design and illustration of the textbook. 
Table 4 Teachers' perception on the design and illustration of Get Smart

\begin{tabular}{|c|c|c|c|c|c|c|}
\hline Statement & SA & A & $\mathrm{D}$ & SD & Mean & STD \\
\hline $\begin{array}{l}\text { 4.The layout and design } \\
\text { is appropriate and clear. }\end{array}$ & $55.3 \%$ & $42.1 \%$ & $2.6 \%$ & $0 \%$ & 3.52 & 0.55 \\
\hline $\begin{array}{l}\text { 5.There is enough white } \\
\text { space to achieve clarity. }\end{array}$ & $36.8 \%$ & $47.4 \%$ & $\begin{array}{l}15.8 \\
\%\end{array}$ & $0 \%$ & 3.21 & 0.70 \\
\hline $\begin{array}{l}\text { 6.The series has a } \\
\text { complete and detailed } \\
\text { table of contents. }\end{array}$ & $50 \%$ & $50 \%$ & $0 \%$ & $0 \%$ & 3.50 & 0.50 \\
\hline $\begin{array}{l}\text { 7.The series has an } \\
\text { appropriate glossary. }\end{array}$ & $34.2 \%$ & $63.2 \%$ & $2.6 \%$ & $0 \%$ & 3.31 & 0.50 \\
\hline $\begin{array}{l}\text { 8. The illustrations are } \\
\text { varied and attractive. }\end{array}$ & $50 \%$ & $44.7 \%$ & $5.3 \%$ & $0 \%$ & 3.44 & 0.60 \\
\hline Statement & SA & A & $\mathrm{D}$ & SD & Mean & STD \\
\hline $\begin{array}{l}\text { 9. The illustrations } \\
\text { stimulate students to be } \\
\text { creative. }\end{array}$ & $7.9 \%$ & $42.1 \%$ & $13.2 \%$ & $\begin{array}{l}36.8 \\
\%\end{array}$ & 2.21 & 1.04 \\
\hline $\begin{array}{l}\text { 10. The illustrations are } \\
\text { functional. }\end{array}$ & $39.5 \%$ & $55.3 \%$ & $5.3 \%$ & $0 \%$ & 3.34 & 0.58 \\
\hline $\begin{array}{l}\text { 11.The illustrations } \\
\text { facilitate students' } \\
\text { learning. }\end{array}$ & $42.1 \%$ & $50 \%$ & $7.9 \%$ & $0 \%$ & 3.34 & 0,60 \\
\hline Overall Mean & \multicolumn{6}{|c|}{3.23} \\
\hline $\begin{array}{l}\text { Overall Standard } \\
\text { Deviation }\end{array}$ & \multicolumn{6}{|c|}{0.42} \\
\hline
\end{tabular}




\section{Accompanying Materials}

The data in table 5 depicts the findings regarding the suitability of the accompanying materials. It shows that the mean for this category is 3.22 , implying that generally, $88.15 \%$ of the teachers agreed on the suitability of the CD-ROM and textbook used as supplementary with Get Smart textbook. In fact, most of them felt that the workbook as well as the supplementary audio resources are appropriate for the learners which indicates on the quality of Get Smart textbook. The results in this category are in line with the findings of Alamri (2208) where teachers considered the accompanying materials appropriate. However, the study of Momand et al. (2019) showed that KSSR book of ELT in Malaysian primary school had no accompanying materials at all, thus making one of the huge weaknesses of KSSR years 6 textbook. These findings suggest that the teachers see the supplementary materials effective and satisfactory that come with the textbook. Thus, Get Smart textbook could be one of the good quality textbooks in terms of supplementary elements as having adequate supplementary materials by a book can be one of the good qualities of textbooks ( (Nimehchisalem \& Mukundan, 2015).

Table 5: teachers' perception on the accompanying materials of Get Smart

\begin{tabular}{|l|l|l|l|l|l|l|}
\hline Statement & SA & A & D & SD & Mean & STD \\
\hline $\begin{array}{l}\text { 12.The workbook that accompanies } \\
\text { the series includes suitable } \\
\text { supplementary activities. }\end{array}$ & $\begin{array}{l}31.6 \\
\%\end{array}$ & $\begin{array}{l}55.3 \\
\%\end{array}$ & $\begin{array}{l}13.2 \\
\%\end{array}$ & $\begin{array}{l}0 \\
\%\end{array}$ & 3.18 & 0.65 \\
\hline $\begin{array}{l}\text { 13.The CD-ROM that accompanies } \\
\text { the series is suitable }\end{array}$ & $\begin{array}{l}36.8 \\
\%\end{array}$ & $\begin{array}{l}52.6 \\
\%\end{array}$ & $\begin{array}{l}10.5 \\
\%\end{array}$ & $\begin{array}{l}0 \\
\%\end{array}$ & 3.26 & 0.64 \\
\hline Overall Mean & \multicolumn{7}{|c|}{3.22} & \\
\hline Overall Standard Deviation & \multicolumn{7}{|c|}{0.05} \\
\hline
\end{tabular}

\section{Language Contents}

Table 5 below indicates that the overall mean for this category is 3.19 which reveals the agreement of most of the teachers on the language content of the textbook. A majority of teachers (85\%) in the study agreed that the textbook has good language contents which allows enhancing student's language, especially their pronunciation, grammar \& vocabulary. From all the items in this category, the pronunciation is reflected with more agreement by all the participants (100\%) implying that it is adequately stressed and focused along all the skills of language . 
Nevertheless, item 23 (To suit students' language needs) in this category is faced with disagreement by some respondents $(31 \%)$. This shows that the language contents used in Get Smart textbook can not meet students' needs. These findings were also consistent with interview results. For instance, one of the interviewees stated as follows when asked about why the contents did not meet students' needs:

"The language content do not suit student's needs because it is not related with the Malaysian context. For example, students cannot relate the four types of weather that is introduced in the book since it is not the same in Malaysia " .(Respondent 1)

Similarly, other interviewees highlighted that the inputs are very unfamiliar, vocabulary is challenging, examples of the textbooks do not relate to students' daily lives, and more specifically they mentioned that the words such as Indication and Octagon in topic 7 on page 71 as some examples of the words that are challenging for students of year three.

In addition, 18. $4 \%$ of the teachers agree that the grammar rules in Get Smart are not presented with simple explanations, thus making it challenging. The interviews also confirmed that the explanation of grammar rules is accompanied with some challenging words and yet impeding the understanding of rules for learners. All of the interviewees believed that the vocabulary in this part are thought-provoking, and they need to do a lot of explanations to facilitate the description of grammar rules for the students. These findings are in conflict with that of Akef and Moosavi (2014) where they found that the teachers and students believed that the grammar rules are presented with simple explanations. This may probably be due to the difference in books since they evaluated Passages Second Edition taught to institute students while Get Smart is taught to primary school students and challenging vocabulary may be difficult for them.

On the other hand, Get Smart has adequate materials for teaching vocabulary which is one of the fundamental points in learning a language. Harmon, Wood, and Kiser (2009) state that, for learners vocabulary development is an important aspect of their language development. It is further described by Nation (2001) that the relationship between language and vocabulary knowledge complements each other. Knowledge of vocabulary enables language use meanwhile language use leads to an increase in vocabulary knowledge. Get Smart helps students to make good use of language to study with all skills. It helps to discover, understand, extend meaning and clarify in a given subject. Good language contents in a textbook help in constructing knowledge. Acquainted and fascinating language is used to motivate understanding and learning. Thus, language content is one of the strengths in Get Smart textbook. 
Table 6: Teachers Perception on the Language Contents of Get Smart

\begin{tabular}{|c|c|c|c|c|c|c|}
\hline Statement & SA & A & $\mathrm{D}$ & SD & Mean & STD \\
\hline $\begin{array}{l}\text { 19.Grammar rules are } \\
\text { presented with clear and } \\
\text { simple explanations. }\end{array}$ & $36.8 \%$ & $44.7 \%$ & $18.4 \%$ & $0 \%$ & 3.18 & 0.73 \\
\hline $\begin{array}{l}\text { 20.The series includes } \\
\text { adequate materials for } \\
\text { teaching vocabulary. }\end{array}$ & $36.8 \%$ & $47.4 \%$ & $15.8 \%$ & $0 \%$ & 3.21 & 0.70 \\
\hline $\begin{array}{l}\text { 21. The series includes } \\
\text { adequate material for } \\
\text { pronunciation work. }\end{array}$ & $36.8 \%$ & $47.4 \%$ & $15.8 \%$ & $0 \%$ & 3.21 & 0.70 \\
\hline $\begin{array}{l}\text { 22.Pronunciation is built } \\
\text { through different types of } \\
\text { activities, such as listening, } \\
\text { speaking, reading, and } \\
\text { writing. }\end{array}$ & $44.7 \%$ & $55.3 \%$ & $0 \%$ & $0 \%$ & 3.44 & 0.50 \\
\hline $\begin{array}{l}\text { 23.Language contents suit } \\
\text { students' language needs. }\end{array}$ & $34.2 \%$ & $34.2 \%$ & $28.9 \%$ & $2.6 \%$ & 3.00 & 0.87 \\
\hline $\begin{array}{l}\text { 24. The materials for teaching } \\
\text { grammar, vocabulary, and } \\
\text { pronunciation are graded in } \\
\text { an appropriate manner. }\end{array}$ & $26.3 \%$ & $57.9 \%$ & $15.8 \%$ & $0 \%$ & 3.11 & 0.65 \\
\hline Statement & SA & A & $\mathrm{D}$ & SD & Mean & STD \\
\hline Overall Mean & \multicolumn{6}{|l|}{3.19} \\
\hline Overall Standard Deviation & 0.14 & & & & & \\
\hline
\end{tabular}




\section{Activities and Exercises}

Table 7 below shows that the overall mean for this category is 3.15 which suggest on the agreement of most of the teachers on the activities and exercises in Get Smart. Majority of the respondents $(94.7 \%)$ showed agreement that the tests and language used in Get Smart textbook is correct and valid. All the exercises and activities in Get Smart textbook help to improve students' language learning. However, almost $30 \%$ of the respondents believed that the Get Smart textbook does not provide them with the models for the final achievement tests. Generally, it is revealed that teachers agree that the activities and exercises of Get Smart are satisfactory however, the book lacks models for final achievement tests The interview results were also consistent with these findings. The interviewees believed that there are enough exercises for each separate language skill in Get Smart textbook but they mentioned that the listening exercises solely depend on the audio and cannot function without audio and the writing exercises do not suit all level of proficiencies. Other interviewees mentioned that less focus on sentence structures, no focus on paragraph writing and no place for asking students to write are some of the issues with exercises and activities in Get Smart textbook. Regarding final achievement tests, two of the interviewees suggested adding a list of questions at the end of each book so that it can be used to evaluate students' overall understanding of the contents, although there is no achievement tests for the students of Get Smart textbook. In relation to this, one interviewee responded as follows:

"There is no final achievement test for lower elementary students in Malaysian schools. In my opinion, it would be good or much easier to evaluate student's achievement, knowledge and understanding if there is a list of questions covering the entire topic at the end of every semester. Students will also feel and know the purpose of studying ' ".(Respondent 3 )

These findings suggest that Get Smart textbook consists of sufficient exercises and activities but lacks the important characteristics that is the diversity in exercises since most of the exercises are focusing on fill-in blanks, matching, and re-arranging the sentences. Exercises and activities are one of the prominent features of the textbooks as they can motivate the students and thus facilitate the learning process (Zohrabi, 2011). 
Table 7: Teachers Perception on Activities and Exercises in Get Smart

\begin{tabular}{|c|c|c|c|c|c|c|}
\hline Statement & SA & $\mathbf{A}$ & $\mathbf{D}$ & SD & Mean & STD \\
\hline $\begin{array}{l}\text { 34. The series provides a variety } \\
\text { of meaningful and mechanical } \\
\text { exercises and activities to } \\
\text { practice language items and } \\
\text { skills. }\end{array}$ & $34.2 \%$ & 55.35 & $10.5 \%$ & $0 \%$ & 3.23 & 0.63 \\
\hline $\begin{array}{l}\text { 35.The series provides } \\
\text { communicative exercises and } \\
\text { activities that help students } \\
\text { carry out their communicative } \\
\text { tasks in real life. }\end{array}$ & $36.8 \%$ & $50 \%$ & $13.2 \%$ & $0 \%$ & 3.23 & 0.67 \\
\hline $\begin{array}{l}\text { 36. Every exercise has a clear } \\
\text { direction. }\end{array}$ & $26.3 \%$ & $65.8 \%$ & $7.9 \%$ & $0 \%$ & 3.18 & 0.56 \\
\hline $\begin{array}{l}\text { 37. There are a reasonable and } \\
\text { appropriate number of exercises. }\end{array}$ & $28.9 \%$ & $50 \%$ & $21.1 \%$ & $0 \%$ & 3.08 & 0.71 \\
\hline $\begin{array}{l}\text { 38. The tests are valid and contain } \\
\text { correct language. }\end{array}$ & $34.2 \%$ & $60.5 \%$ & $5.3 \%$ & $0 \%$ & 3.29 & 0.56 \\
\hline $\begin{array}{l}\text { 39. The series provides periodical } \\
\text { revisions for diagnostic purposes. }\end{array}$ & $28.9 \%$ & $57.9 \%$ & $13.2 \%$ & $0 \%$ & 3.16 & 0.64 \\
\hline $\begin{array}{l}\text { 40.The series provides models } \\
\text { for final achievement tests. }\end{array}$ & $21.1 \%$ & $\begin{array}{l}50 \\
\%\end{array}$ & $28.9 \%$ & $0 \%$ & 2.92 & 0.71 \\
\hline Overall Mean & \multicolumn{6}{|l|}{3.15} \\
\hline Overall Standard Deviation & \multicolumn{6}{|l|}{0.12} \\
\hline
\end{tabular}

\section{Social and Cultural Contexts}

Table 8 below indicates the descriptive statistics for this category. It is clear that the mean for this category is 2.73 and being the lowest mean in questionnaire categories suggesting that the respondents disagree to the Get Smart textbook in terms of social and cultural contexts. About $55.3 \%$ of the respondents showed disagreement with the belief that the students can understand about the inner lives of the characters used in Get Smart textbook and $31.5 \%$ of the teachers agreed that the social and cultural contexts in Get Smart textbook are not comprehensible to the learners. These findings show that the social and cultural contents of Get Smart textbook do not suit Malaysian context. In fact, most of the social and cultural contexts in Get Smart are reflecting Western culture. For example, the topic of food which does not show the foods of Malaysian context. In addition, interview data showed similar 
findings. For instance, whether the contents suit social and cultural contexts, an interviewee responded as below:

"None of the contents in the textbook cover Malaysian society or culture i.e. no relevant socio-cultural information embedded within content which made it challenging for the students to comprehend. For instance, the examples of food introduced in topic 6 as well as the names used in the textbook" (Respondent 2)

These findings are dissimilar with that of Alamri (2008) and Momand et al., (2019) where they found that the respondents totally agreed that the book was socially and culturally appropriate and free of any stereotypical images or information. Nonetheless, with the exception that Alamri found that the book could not allow students to learn about the inner lives of the characters used in the book something consistent with this study. Taking into consideration the social and cultural context of the textbook is a crucial element as Angell, DuBravac, and Gonglewski (2008) believe that ELT textbooks should take into consideration the local social and cultural context so that learners' needs are met.. These findings show that Get Smart textbook does not meet the social and cultural context of Malaysia as the book reflects a Western social and cultural context. With unfortunate, Get Smart textbook lacks this essential quality and needs to be improved in terms of social and cultural issues.

Table 8: Teachers Perception on the Social and Cultural Contexts in Get Smart

\begin{tabular}{|l|l|l|l|l|l|l|}
\hline Statement & SA & A & D & SD & Mean & STD \\
\hline $\begin{array}{l}\text { 25.The social and cultural } \\
\text { contexts in the series are } \\
\text { comprehensible. }\end{array}$ & $21.1 \%$ & $47.4 \%$ & $28.9 \%$ & $2.6 \%$ & 2.87 & 0.77 \\
\hline $\begin{array}{l}\text { 26.Students can learn about } \\
\text { the inner lives of the } \\
\text { characters used in the series. }\end{array}$ & $0 \%$ & $44.7 \%$ & $34.2 \%$ & $21.1 \%$ & 2.24 & 0.78 \\
\hline $\begin{array}{l}\text { 27.The series expresses } \\
\text { positive views of ethnic } \\
\text { origins, occupations, age } \\
\text { groups, social groups and } \\
\text { disability. }\end{array}$ & $23.7 \%$ & $60.5 \%$ & $15.8 \%$ & $0 \%$ & 3.08 & 0.63 \\
\hline $\begin{array}{l}\text { Overall Mean } \\
\text { Overall Standard Deviation }\end{array}$ & 0.43 & & & & & \\
\hline
\end{tabular}

The overall findings from questionnaire data and interviews show that teachers showed agreement with almost all the features of Get Smart textbook thus, 
making it one of the suitable textbooks for year three students in Malaysian schools. However, there are some specific issues with Get Smart textbook that need to be taken into consideration. For instance, the illustrations in the book need to motivate students' creativity, vocabulary should not be challenging, the books should meet students' needs socially and culturally, grammar rules be explained with simple words, achievement tests questions be added, listening activities should not only depend on audio, and there should be focus on sentence structure and paragraph writing.

\section{CONCLUSION}

This study his study was conducted in Malaysian primary schools to find out if Get Smart English Language teaching textbook is a good textbook. The study also evaluated the textbook in terms of its strengths and weaknesses. The overall findings showed that the teachers agreed to the whole features of the book implying they believed the book is satisfactory. Nonetheless, there were some minor issues which need to be improved. These features are the recommendations of the study so that the Malaysian ministry of education take them into consideration. First, the lack of creativity in illustrations, challenging vocabulary, lack of social and cultural suitability, use of difficult words in grammar explanations, lack of achievement test questions, lack of independent use in listening activities, and the lack of emphasis on writing activities in terms of sentence and paragraph writing.

\section{References}

AbdelWahab, M. M. (2013). Developing an English language textbook evaluative checklist. IOSR Journal of Research \& Method in Education, 1(3), 55-70.

Akef, K., \& Moosavi, Z. (2014). Iranian EFL teachers' and students' textbook evaluation. The Iranian EFL Journal, 10(6), 1.

Al-Hajailan, T. (2003). Teaching English in Saudi Arabia. Riyadh: Aldar Alsawtia for Publishing and Distribution.

Alamri, A. A. M. (2008). An evaluation of the sixth grade English language textbook for Saudi boys' schools. Unpublished MA thesis, Riyath, Saudi Arabia.

Angell, J., DuBravac, S., \& Gonglewski, M. (2008). Thinking globally, acting locally: Selecting textbooks for college-level language programs. Foreign Language Annals, 41(3), 562-573.

Ansary, H., \& Babaii, E. (2002). Universal characteristics of EFL/ESL textbooks: A step towards systematic textbook evaluation. The Internet TESL Journal, $8(2), 1-9$.

Bryman, A., Becker, S., \& Sempik, J. (2008). Quality criteria for quantitative, qualitative and mixed methods research: A view from social policy. International Journal of Social Research Methodology, 11(4), 261-276.

Chegeni, N., Kamali, B., Noroozi, A., \& Chegeni, N. (2016). General English Textbook Evaluation: A Closer Look at "Four Corners". Theory and practice in language studies, 6(12), 2325-2330. 
Cohen, L., Manion, L., Morrison, K., \& Morrison, R. (2007). Research methods in education" Routledge. In: USA and Canada.

Demir, Y., \& Ertas, A. (2014). A suggested eclectic checklist for ELT coursebook evaluation. Reading, 14(2).

Dörnyei, Z., \& Taguchi, T. (2009). Questionnaires in second language research: Construction, administration, and processing: Routledge.

Ereksoussy, M. (1993). Evaluating the English language textbook studied in the first year at girls' intermediate schools in Saudi Arabia. Unpublished MA dissertation, King Saud University, Riyadh.

Harmon, J. M., Wood, K. D., \& Kiser, K. (2009). Promoting vocabulary learning with the interactive word wall. Middle School Journal, 40(3), 58-63.

Hutchinson, T., \& Waters, A. (1987). English for specific purposes: Cambridge university press.

King, N., Cassell, C., \& Symon, G. (2004). Using templates in the thematic analysis of text. Essential guide to qualitative methods in organizational research, 2, 256-270.

Malterud, K. (2001). Qualitative research: standards, challenges, and guidelines. The lancet, 358(9280), 483-488.

McGrath, I. (2002). Materials evaluation and design for language teaching: Edinburgh University Press.

Miles, M. B., Huberman, A. M., Huberman, M. A., \& Huberman, M. (1994). Qualitative data analysis: An expanded sourcebook: sage.

Mukundan, J., \& Kalajahi, S. A. R. (2013). Evaluation of Malaysian English language teaching textbooks. International Journal of Education and Literacy Studies, 1(1), 38-46.

Nation, I. S. (2001). Learning vocabulary in another language: Ernst Klett Sprachen.

Nimehchisalem, V., \& Mukundan, J. (2015). Refinement of the English Language Teaching Textbook Evaluation Checklist. Pertanika Journal of Social Sciences \& Humanities, 23(4).

Radhakrishna, R. B. (2007). Tips for developing and testing questionnaires/instruments. Journal of extension, 45(1), 1-4.

Richards Jack, C., \& Rodgers, T. S. (2001). Approaches and Methods in Language Teaching. Cambridge UK.

Sandelowski, M. (1995). Qualitative analysis: What it is and how to begin. Research in nursing \& health, 18(4), 371-375.

Sarem, S. N., Hamidi, H., \& Mahmoudie, R. (2013). A critical look at textbook evaluation: A case study of evaluating an ESP course-book: English for international tourism. International Research Journal of Applied and Basic Sciences, 4(2), 372-380.

Sheldon, L. E. (1988). Evaluating ELT textbooks and materials. ELT journal, 42(4), 237-246. 
Skarupova, K., \& Blinka, L. (2013). Systematic review of online gaming addiction measures. Paper presented at the JOURNAL OF BEHAVIORAL ADDICTIONS.

Soleimani, H., \& Dabbaghi, A. (2012). Textbook evaluation: A reflection on the New Interchange Series. International Journal of Research Studies in Language Learning, 1(2), 19-32.

Thein, N. (2006). Evaluating the suitability and effectiveness of three English coursebooks at Myanmar Institute of Technology. Unpublished MA thesis, University of Thailand. Thailand.

Tomlison, C. (2001). How to differentiate instruction in mixed classrooms. In: Alexandria, VA: ASCD.

Zohrabi, M. (2011). An Evaluation of Classroom Activities and Exercises in ELT Classroom for General Purposes Course. English Language Teaching, 4(1), 141-151. 
AKSARA: Jurnal Ilmu Pendidikan Nonformal

P-ISSN $\underline{2407-8018}$ E-ISSN $\underline{2721-7310}$ DOI prefix $\underline{10.37905}$

Volume 07 (02) Mei 2021

http://ejurnal.pps.ungac.id/index.php/Aksara 